\title{
EMULGEL FORMULATION OF PURIFIED EXTRACT OF MORINGA (Moringa oleifera L.) LEAF
}

Tutik Wuryandari ${ }^{1}$, Nining Sugihartini ${ }^{2}$, Kintoko $^{2}$

${ }^{1}$ Master Program of Pharmacy, Ahmad Dahlan University, ${ }^{2}$ Faculty of Pharmacy, Ahmad Dahlan University, Yogyakarta, Indonesia

\section{ABSTRACT}

Moringa oleifera, known as moringa, is reported to have a high source of natural antioxidants, especially vitamin E. The formulation of purified Moringa leaf extract is needed so that the vitamin E content in it is more maximal. This study aimed to determine the levels of vitamin E in extracts after purification, physical property test of emulgel with variations in extract concentration and vitamin E levels in emulsions. The study was started from the extraction using maceration method with petroleum ether solvent, followed by extract purification using column chromatography with n-hexane solvent. The results of the purified extract were then formulated into emulgel with three concentrations of 3\% (F1), 6\% (F2) and 9\% (F3). Emulgel was then evaluated for physical characteristics $(\mathrm{pH}$, viscosity, adhesion, dispersion and stability). Determination of vitamin E levels was carried out on purified extract samples and on each formula. The results of non-specific standardization of extracts included ash content, acidic insoluble ash content were higher than those of Indonesian Herbal Pharmacopoeia literature and drying losses were lower compared to literature. Specific standardization of extracts was the content of vitamin E in $1.40 \%$ PE extract and $8.02 \%$ purified extract. In the test of emulgel physical characteristics, an increase in the concentration of the extract caused an increase in viscosity and decreased emulgel dispersion power. Whereas, the $\mathrm{pH}$ and sticky power remained the same. Storage hds an effect on decreasing the physical characteristics of emulsions especially on adhesion. Increased extracts also caused an increase in the levels of vitamin E in the purified extract of moringa leaf emulgel.

Keywords: Emulgel; Moringa oleifera; standardize extract; vitamin E

\section{ABSTRAK}

Moringa oleifera, yang dikenal dengan kelor, dilaporkan memiliki sumber antioksidan alami yang tinggi terutama kandungan vitamin E. Formulasi ekstrak daun kelor yang sudah terpurifikasi diperlukan agar kandungan vitamin E di dalamnya lebih maksimal. Penelitian ini bertujuan untuk mengetahui kadar vitamin E dalam ekstrak setelah purifikasi, uji sifat fisik emulgel dengan variasi konsentrasi ekstrak dan kadar vitamin E dalam emulgel. Penelitian dimulai dari penyarian dengan metode maserasi menggunakan pelarut petroleum eter dilanjutkan purifikasi ekstrak menggunakan kromatografi kolom dengan pelarut n-heksan. Hasil ekstrak terpurifikasi selanjutnya diformulasi menjadi emulgel dengan tiga konsentrasi yaitu 3\% (F1), 6\% (F2) dan 9\% (F3). Emulgel selanjutnya dilakukan evaluasi sifat fisik ( $\mathrm{pH}$, viskositas, daya lekat, daya sebar dan stabilitas). Penetapan kadar vitamin E dilakukan pada sampel ekstrak terpurifikasi dan pada masing-masing formula. Hasil standarisasi non spesifik ekstrak meliputi kadar abu, kadar abu tidak larut asam yang lebih tinggi dari pustaka Farmakope Herbal Indonesia dan susut pengeringan yang lebih rendah dibandingkan pustaka. Standarisasi spesifik ekstrak adalah kandungan vitamin E dalam ekstrak PE 1,40\% dan ekstrak terpurifikasi $8,02 \%$. Pada uji sifat fisik emulgel, peningkatan konsentrasi ekstrak menyebabkan peningkatan viskositas dan menurunnya daya sebar emulgel. Sedangkan, pH dan daya lekat tetap. Penyimpanan berpengaruh pada penurunan sifat fisik emulgel terutama pada daya lekat. Peningkatan ekstrak juga menyebabkan peningkatan kadar vitamin E pada emulgel ekstrak terpurifikasi daun kelor.

Kata kunci: Emulgel; Moringa oleifera; standarisasi ekstrak; vitamin E

Correspondence: Nining Sugihartini, Faculty of Pharmacy, Universitas Ahmad Dahlan, Yogyakarta, Indonesia. E-mail: nining.sugihartini@pharm.uad.ac.id

pISSN:2355-8393 • eISSN: 2599-056x • doi: http://dx.doi.org/10.20473/fmi.v55i1.12545

- Fol Med Indones. 2019;55:17-24 • Received 28 Apr 2017 • Accepted 24 Aug 2017

- Open access under CC-BY-NC-SA license • Available at https://e-journal.unair.ac.id/FMI/ 


\section{INTRODUCTION}

Moringa oleifera, known as moringa, has leaves that are usually used as vegetables. Moringa is one of the plants reported to be a source of natural antioxidants (Anwar et al 2007). The content of vitamin $\mathrm{E}$ in Moringa leaves has the highest level of $77 \mathrm{mg} / 100 \mathrm{~g}$ (Moyo et al 2011). Vitamin $\mathrm{E}$ is the most active form of a-tocopherol. This vitamin is a fat-soluble vitamin (Winarsi 2007). Vitamin E causes moringa to be used for skin preparations.

Various research and development are an effort to improve product quality and safety. One method used is standardizing extracts. The degree of active compounds is an absolute requirement for product quality. Standardization is a series of parameters, procedures and methods of measurement whose results are related to quality that meets standards and guarantees product stability. The results of the extraction process can produce specific and non-specific parameters of standardized extracts and are expected to be able to show quality (Azizah \& Salamah 2013).

To make topical preparations for purified extract of Moringa leaves, the content of vitamin $\mathrm{E}$ for the skin needs suitable base. Topical bases, such as ointments, creams, and lotions, have several disadvantages because of their stickiness, low dispersion and problematic stability so patients prefer not to use them. Emulsions are superior in patient use and reception while gels have a higher water component which allows the spread of wider drugs than ointments and creams. Although gel has advantages but there are limitations in the delivery of hydrophobic drugs. Thus, an emulgel form is used to overcome the delivery of hydrophobic drugs. Emulgel is used for the skin because it has beneficial characteristics, such as easily applied, easy to release drugs, moisturize the skin, more stable and good in appearance (Panwar et al 2011).

\section{MATERIALS AND METHODS}

The tools used were rotary vaccum evaporator (heidolph), sticky power test equipment, dispersion power, chromatography column, and TLC-densitometer (Camag TLC Scanner). The test material used in this study was Moringa oleifera $L$. leaf obtained from Banjaratma Brebes village, Central Java. Chemicals needed for petroleum ether (Bratachem) were n-hexane (pa), ethyl acetate (pa), Ethanol (pa), Silica (for Chromatography), emulgel composers with pharmaceutical quality include (stearyl alcohol, stearic acid, PEG-400, cetyl alcohol, carbopol 940, Dinarium EDTA, Methyl paraben, Propil paraben, Triethanolamine) and standard vitamin $\mathrm{E}$ as atocopherol (Sigma Aldrich).

\section{Manufacture of petroleum ether extract and purificated moringa leaf extract}

Moringa leaf dry powder was extracted with petroleum ether using maceration method. The filtrate was filtered and evaporated by vaccum rotary evaporator then thick extract was weighed and the results were calculated by the following equation:

$$
\% \text { Rendement }=\frac{\text { extract weight }}{\text { powder weight }} \times 100 \%
$$

The purified extract was made by column chromatography using n-hexane solvent. Fifty grams of PE extract was put into the chromatographic column after column preparation using the stationary phase of silica gel for chromatography with the n-hexane mobile phase. The elution process was carried out until the desired component exited the column. The collection of fractions was done using bottles that had been marked. Fraction was accommodated every 1 liter. Each component of vitamin $\mathrm{E}$ was detected by using TLC. The results of the purified extract were then used to make the emulgel formula.

\section{Extract specifications}

Specific parameters were carried out by determining vitamin E levels using TLC-densitometer. Whereas, test for non-specific parameters includes ash content, acid insoluble ash content and drying losses by referring to Indonesian Herbal Pharmacopoeia supplement III (2013).

\section{Preparation of emulgel formulation of purified extract of moringa}

The purified extract emulgel formula for Moringa leaves is presented in Table I with extract concentrations of $3 \%, 6 \%$ and $9 \%$. The formula refers to the modified formula by Gaikwad and Kale (2011). 
Table 1. Emulgel formula with variations in concentrations of 3\%, 6\% and $9 \%$ purified extract of Moringa leaf

\begin{tabular}{lccc}
\hline & \multirow{2}{*}{ Composition } & \multicolumn{3}{c}{ Formula (\%) } \\
\cline { 2 - 4 } & I & II & III \\
\hline Purified Extract & 3 & 6 & 9 \\
Stearyl alcohol & 5 & 5 & 5 \\
Stearic acid & 2 & 2 & 2 \\
PEG 400 & 2 & 2 & 2 \\
Cetyl alcohol & 1 & 1 & 1 \\
Carbopol 940 & 0.5 & 0.5 & 0.5 \\
Disodium EDTA & 0.02 & 0.02 & 0.02 \\
Na Methyl paraben & 0.3 & 0.3 & 0.3 \\
Na Propyl paraben & 0.06 & 0.06 & 0.06 \\
Triethanolamine & 0.5 & 0.5 & 0.5 \\
Perfume & q.s & q.s & q.s \\
Distilled water & 100 & 100 & 100 \\
\hline Note: Formula I: Moringa leaf extract emulgel with a concentration of 3\%, Formula \\
\multicolumn{1}{c}{ II: Moringa leaf extract emulgel with a concentration of $6 \%$, Formula III: } \\
\multicolumn{2}{c}{ Moringa leaf extract emulgel with a concentration of 9\% }
\end{tabular}

\section{Test of physical characteristics of emulgel formulation of purified extract of moringa}

The organoleptic test was carried out by observing the shape, color and smell of emulgel. Emulgel $\mathrm{pH}$ measurements were applied with $\mathrm{pH}$ paper. The emulgel viscosity test was applied with the Brookfield viscometer

\section{Sticky power test}

The sticky power test is carried out by attaching 1 gram of cream over one glass object with another glas object. The cream is applied between two glass objects and then pressed with a load of $1 \mathrm{~kg}$ for 5 minutes on the test equipment. After 5 minutes the load is released and the time is recorded when the two objects are released (Naibaho et al 2013).

\section{Spread power test}

A supply of 0.5 grams is placed on a transparent glass below which a graph paper is then then covered with glass on top and given the child weigh as a load. For 1 minute left and measured the diameter of the cream that spreads, then give the load above $50 \mathrm{~g}, 100 \mathrm{~g}, 150 \mathrm{~g}$ and $200 \mathrm{~g}$. Each addition of the load is left to stand for 1 minute and note the diameter of the cream that spreads (Sari et al 2015).

\section{Stability test}

Stability test was carried out by organoleptic observation, $\mathrm{pH}$, viscosity, adhesion and dispersion on day 1 and day 90 of the preparation at 400C (Priani et al 2014).

\section{Data analysis}

Tests for the stability of the physical characteristics of emulgel preparations obtained on day 1 and storage for 3 months were analyzed statistically by homogeneity test and continued with independent t-test. Vitamin $\mathrm{E}$ levels were analyzed by plotting the area with a standard curve to calculate the levels in the sample then analyzed using homogeneity test and continued with one-way ANOVA.

\section{RESULTS}

Moringa leaf powder extraction using PE solvents because vitamin $\mathrm{E}$ is insoluble in water but soluble in fats and organic solvents. The test results showed the yield of maceration obtained as much as $5.10 \%$. The extract obtained was then purified which previously carried out the optimization of the n-hexane mobile phase: ethyl acetate (5:1) and the stationary phase of silica gel F60. The test results show the price of Rf for the standard vitamin E is 0.68 as presented in Fig. 1.

The results of PE extract were then standardized with specific and non-specific parameters. The PE extract produced in the form of thick extract with a brownish green color and does not smell. Specifications based on vitamin E levels of PE extract showed that the vitamin E leaf of Moringa leaves was $1.40 \pm 0.08 \%$. Non-specific standardization results can be seen in Table 2 . 


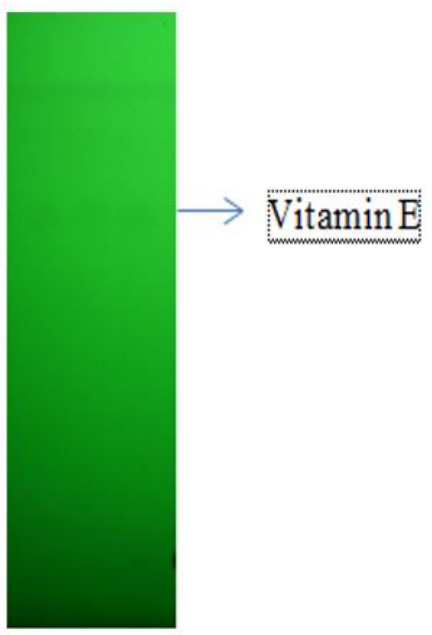

1

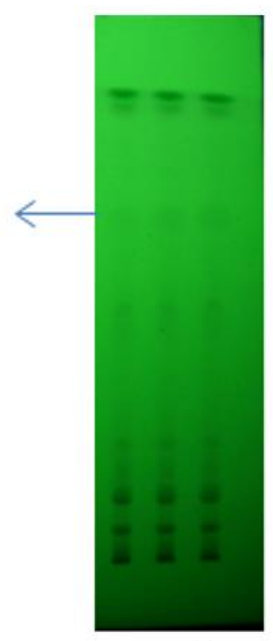

2
Motion phase: hexane: et.ac (5: 1$)$

Silent phase : silica gel F60

Detection : UV 254

Fig. 1. The results of the TLC extract are detected by UV254 light; (1) standard vitamin E, (2) Petroleum ether extract.

Table 2. Data on non-specific standardization of Moringa oleifera leaves

\begin{tabular}{lcccc}
\hline \multicolumn{1}{c}{ Non-specific parameters } & \multicolumn{2}{c}{ Simplisia } & Extract \\
\cline { 2 - 5 } & Results & FHI provisions* & Results & FHI provisions* \\
\hline Total ash content $(\%)$ & $8.91 \pm 0.01$ & No more than 7.5 & $9.01 \pm 0.33$ & No more than 9.0 \\
Levels of acid insoluble ash & $1.62 \pm 0.27$ & No more than 0.9 & $1.83 \pm 0.23$ & No more than 0.9 \\
$\begin{array}{l}\text { (\%) } \\
\text { Drying shrinkage }(\%)\end{array}$ & $7.20 \pm 0.00$ & No more than 12 & $9.43 \pm 0.00$ & - \\
\hline
\end{tabular}

Note: * FHI provisions (Indonesian Herbal Formulary Supplement III 2013)

The purpose of determining the ash content is to provide an overview of internal and external mineral content from the initial process to the formation of extracts. In addition, it also controls the contamination of organic matter such as soil, sand which is often included in preparations from natural materials (Azizah \& Salamah 2013).

Moringa leaf PE extract was obtained then purified by column chromatography using n-hexane solvent for the purpose. The extract obtained was purer. The results of the analysis by TLC showed that bottles containing vitamin $\mathrm{E}$ were bottles 2, 9, 10 and 11 with $\mathrm{Rf} 0.70$; $0.68 ; 0.70 ; 0.75$ as presented in Figure 2.

The fractions contained in bottles 2, 9, 10 and 11 were then evaporated until a purified extract was obtained. The results obtained were in the form of half-solid orange yellow with a yield of 19.04 grams. The purified extract was then used to make emulgel preparations as shown in Figure 3.

Each preparation was then evaluated for physical characteristics to ensure the quality of the preparation. The results of the physical characteristics test are presented in Table 3.

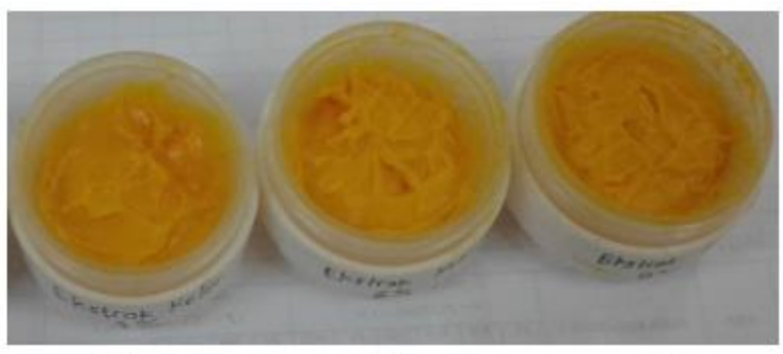

F1

F2

F3

Fig. 3. Results of the Moringa leaf extract emulgel formula with a concentration of $3 \%(\mathrm{~F} 1), 6 \%$ (F2) and 9\% (F3).

The organoleptic emulgel test resulted aromatic smell and orange-yellow in color. PH examination was carried out in order to determine the safety of a topical preparation when used on the skin so as not to irritate the skin and caused scaly skin. The $\mathrm{pH}$ tolerance of the skin ranges from 4.5-6.0 (Smaoui et al 2013). Moringa leaf extract formula had a $\mathrm{pH}$ of 7 so that the preparation did not meet the $\mathrm{pH}$ tolerance range requirements but was still considered safe in use because of its neutral $\mathrm{pH}$. 


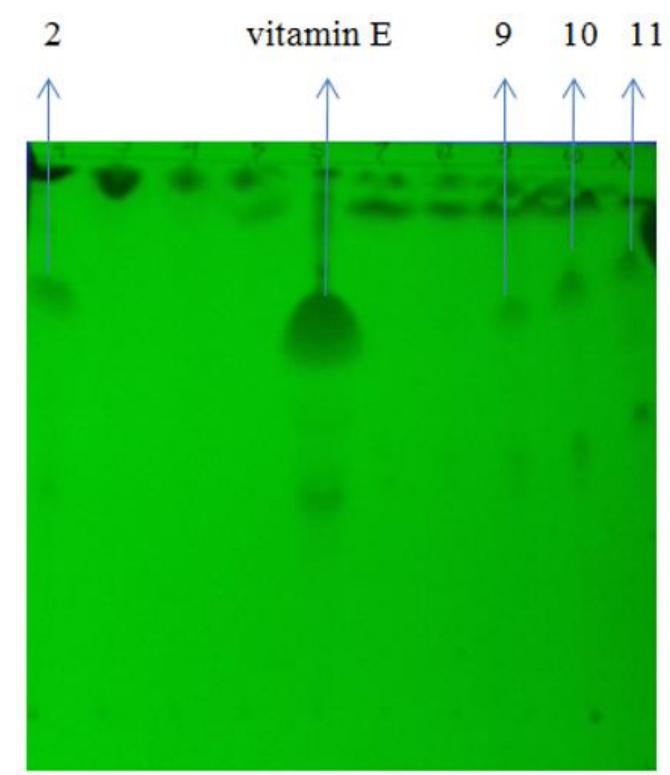

Motion phase: hexane: et.ac $(5: 1)$

Silent phase : silica gel F60

Detection : UV 254

Fig. 2. Results of TLC elution from column chromatography extract of Moringa leaves in bottles 2, 9.10 and 1.

Table 3. The results of the physical characteristic observation of moringa leaf extract emulgel

\begin{tabular}{|c|c|c|c|c|}
\hline \multicolumn{2}{|l|}{ Evaluation } & \multicolumn{3}{|c|}{ Observaton results } \\
\hline & & F1 & $\mathrm{F} 2$ & F3 \\
\hline Organoleptic & Form & emulgel & emulgel & emulgel \\
\hline & Color & orange & orange & orange \\
\hline & Smell & aromatic & aromatic & aromatic \\
\hline $\mathrm{pH}$ & & $7 \pm 0$ & $7 \pm 0$ & $7 \pm 0$ \\
\hline Viscosity (cps) & & $5 \overline{41} 66.67 \pm 251.7$ & $6 \overline{5233.33 \pm 152.8}$ & $70133.33 \pm 351.19$ \\
\hline Adhesion (s) & & $12.0 \pm 0$ & $12.33 \pm 0.58$ & $12 . \overline{0 \pm 0} 0$ \\
\hline Spreadability $(\mathrm{cm})$ & $200 \mathrm{~g}$ & $4.87+0.06$ & $4.80+0$ & $4.77+0.15$ \\
\hline
\end{tabular}

The viscosity test aims to determine the viscosity value of a preparation expressed in centipoises (cps). The higher the viscosity value, the higher the viscosity value. Increasing the concentration of extract causes an increase in viscosity.

Adhesion test is intended to see how long the emulgel's ability to stick when it is used. The longer the emulgel is attached, the longer the penetration time of the drug into the skin. Requirements for adhesion to topical preparations are not less than 4 seconds (Sari et al 2015). The test results of the stickiness of purified extract formula of Moringa leaves are more than 4 seconds so that the emulgel is able to adhere well to the skin.

Spread test was conducted to see the ability of the preparation to spread on the skin, where a preparation should have good dispersion to ensure satisfactory administration of medicinal ingredients (Naibaho et al 2013). Good dispersion requirements for topical preparations are 5-7 $\mathrm{cm}$ (Sari et al 2015).

Stability test is used to determine whether the preparation can last throughout the storage period and use to ensure the identity, strength, quality and purity of the product. Instability can be marked by changes in color, odor, changes in consistency and other physical changes. The physical stability test of the preparation was carried out by storing emulgel at $400 \mathrm{C}$ for 90 days. The parameters used in the physical stability test were organoleptic test, $\mathrm{pH}$, viscosity, adhesion and dispersion during storage. Storage at $370 \mathrm{C}-450 \mathrm{C}$ for 3 months without instability shows that the product is stable at room temperature (250C-300C) for approximately one year by assuming that the reaction that occurs at an elevated temperature is the same as the reaction at room temperature (Dewi et al 2014). 
Table 4. Data on physical stability of Moringa leaf extract emulgel preparation

\begin{tabular}{lllll}
\hline \multirow{2}{*}{ Evaluation } & \multicolumn{3}{c}{ Observation results } \\
\cline { 2 - 5 } & & \multicolumn{1}{c}{ F1 } & \multicolumn{1}{c}{ F2 } \\
\hline $\mathrm{pH}$ & Day 1 & $7 \pm 0$ & $7 \pm 0$ & $7 \pm 0$ \\
& Day 90 & $7 \pm 0$ & $6,67 \pm 0,58$ & $6,67 \pm 0,58$ \\
Viscosity (cps) & Day 1 & $54166.67 \pm 251.7$ & $65233.33 \pm 152.8$ & $70133.33 \pm 351.19$ \\
& Day 90 & $50966.67 \pm 585.9$ & $61733.33 \pm 251.66$ & $68233.33 \pm 450.93$ \\
Adhesion (seconds) & Day 1 & $12.0 \pm 0$ & $12.33 \pm 0.58$ & $12.0 \pm 0$ \\
& Day 90 & $2.33 \pm 0.58$ & $1.67 \pm 0.58$ & $2.33 \pm 0.58$ \\
Spread (cm) & $200 \mathrm{~g} \mathrm{(1)}$ & $4.87 \pm 0.06$ & $4.80 \pm 0$ & $4.77 \pm 0.15$ \\
& $200 \mathrm{~g}(90)$ & $4.60 \pm 0$ & $4.73 \pm 0.06$ & $5.27 \pm 0.06$ \\
\hline
\end{tabular}

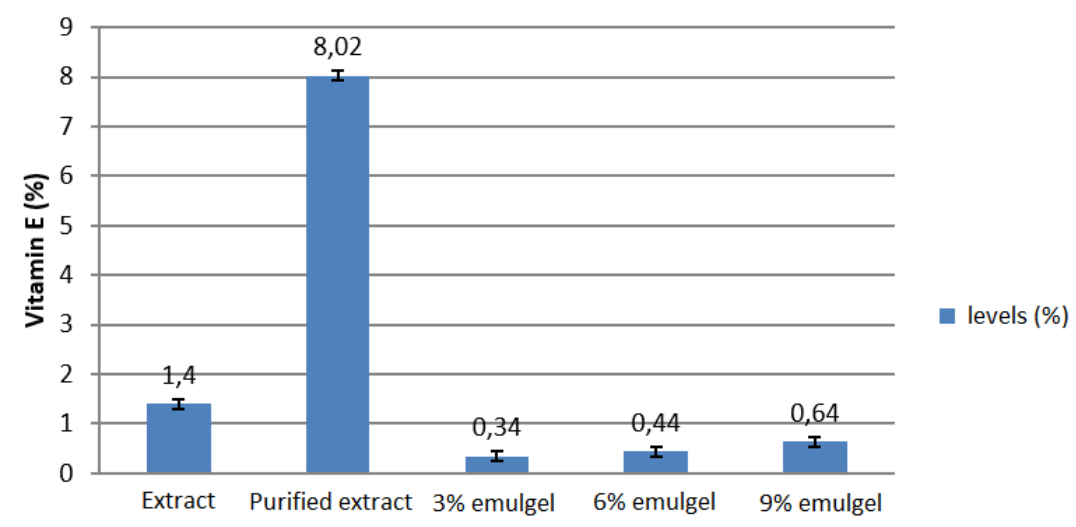

Test samples

Fig. 4. Vitamin E levels in extracts, purified extracts and emulgel formulas.

This study also evaluated vitamin $\mathrm{E}$ levels in PE extracts, purified extracts and emulsions. The value of vitamin E can be determined using Tensitometry TLC to observe the content of vitamin $\mathrm{E}$ in the ingredients. The highest content of vitamin $\mathrm{E}$ was found in purified extract with a grade of $8.02 \%$. This is because the impurity amount was lower than the $1.40 \%$ PE extract. Increasing the concentration of extracts on emulgel causes vitamin $\mathrm{E}$ levels to increase. Emulgel formula contained vitamin E in F1 (3\%), F2 (6\%) and F3 (9\%) as much as $0.34 \% ; 0.46 \%$ and $0.63 \%$ respectively. The results of determining vitamin $\mathrm{E}$ levels are shown in Figure 4.

Vitamin E levels obtained from extracts, purified extracts and emulgel formulas were then statistically tested with one way ANOVA. The statistical test results are presented in Table 5 .

\section{DISCUSSION}

In non-specific standardization of total ash content in Moringa leaves exceeded the standards of Indonesian
Herbal Pharmacopoeia as well as for insoluble ash content. This is possible due to high levels of minerals and inorganic compounds in the material. The parameters of drying losses are intended to see the content of volatile compounds both in simplicia and in extracts. According to Indonesian Herbal Pharmacopoeia (2013), the drying shrinkage is not more than $12 \%$, so the extract met the requirements according to the literature.

Table 5. LSD test results for vitamin E extract, purified extract and Moringa leaf emulgel

\begin{tabular}{lcl}
\hline Treatment Pair & Sig & \multicolumn{1}{c}{ Results } \\
\hline E vs PFE & 0.000 & Significantly different \\
PFE vs F1 & 0.000 & Significantly different \\
PFE vs F2 & 0.000 & Significantly different \\
PFE vs F3 & 0.000 & Significantly different \\
F1 vs F2 & 0.349 & Not significantly different \\
F1 vs F3 & 0.031 & Significantly different \\
F2 vs F3 & 0.156 & Not significantly different \\
\hline Note: E: Extract, PFE: Purified extract, F1: 3\% Emulgel, F2: \\
\multicolumn{2}{c}{ 6\% Emulgel, F3: Emulgel 9\% }
\end{tabular}


Specific standardization is vitamin $\mathrm{E}$ levels in $\mathrm{PE}$ extract which is $1.40 \pm 0.08 \%$, while terpurified extract contains $8.02 \pm 0.27 \%$. PE extract has a lower vitamin $\mathrm{E}$ content because it still contains a lot of impurities while the purified extract has a higher content of vitamin $\mathrm{E}$ by limiting as little as possible the impurities that follow.

The test of the physical characteristics of Moringa leaf emulgel preparations had a $\mathrm{pH}$ of 7 which was still considered safe in use because of its neutral $\mathrm{pH}$. The viscosity of the preparation increases this shows that the increase in the concentration of the extract causes the preparation to become thicker and has a smaller spread because the viscosity increases so that the preparation is more difficult to spread. Adhesion is not affected by an increase in extract concentration.

Stability test on storage shows that organoleptic emulgel does not change shape, odor, or changes in color after storage for 90 days. This showed that the purified emulgel extract was declared organoleptically stable. The results of the $\mathrm{pH}$ statistic test showed no significant difference on day 1 and day $90(\mathrm{P}=0.339>0.05)$. Similarly, the emulgel viscosity test results. Although the emulgel viscosity with variations in Moringa leaf extract concentration (F1, F2 and F3) was lower on the 90th day but still relatively stable. The effect of increasing temperatures can cause lipids to become somewhat liquid. However, the results of the statistical test showed a significant difference in emulgel viscosity on day 1 and day $90(\mathrm{P}=0.947>0.05)$.

The test of adhesion of F1, F2 and F3 emulgel has a sharp decrease after being stored for 90 days. Emulgel with the addition of extract contains fat and oil tend to be more liquid with an increase in temperature so that the stickiness becomes smaller. Adherence after storage becomes ineligible because it is less than 4 seconds. The results of the independent t-test statistical test showed that $\mathrm{P}=0.00,<0.05$ means that there were significant differences before and after storage at sticky power. Spread power test was relatively stable, statistical data showed that there were no significant differences after storage $(\mathrm{P}=0.156,>0.05)$.

The results of TLC densitometry of vitamin $\mathrm{E}$ on extracts, purified extracts and emulgel preparations showed significant differences between PE extracts and purified extracts. This shows that the purification process causes the vitamin E content to increase significantly. Significant differences were also seen between purified extracts with all emulsions. emulgel can be influenced by the nature of vitamin $E$ which is easily degraded due to the influence of light and temperature. The difference in the concentration of extract also causes the levels of vitamin $\mathrm{E}$ in the emulgel to have significant differences between F1 and F3.

\section{CONCLUSION}

The results of the physical characteristics of emulgel preparations tended to meet the requirements but at storage, it caused the stickiness of all preparations to decrease significantly. We suggest for further research to put storage preferably at low temperatures and protected from light, so it is possible to be more stable. The highest level of vitamin $\mathrm{E}$ was found in purified PE extract because there were fewer impurities. This purified extract caused good organoleptic preparations which were bright orange. Increasing the concentration of extract will increase the levels of vitamin $\mathrm{E}$ from emulsions so that $9 \%$ emulgel had the highest content of vitamin E.

\section{REFERENCES}

Anwar F, Latif S, Ashraf M, Gilani AH (2007). Moringa oleifera: A Food Plant with Multiple Medicinal Uses, Phytotherapy Research. Wiley InterScience 21, 17-25

Azizah B, Salamah N (2013). Standarisasi parameter non spesifik dan perbandingan kadar kurkumin ekstrak etanol dan ekstrak terpurifikasi rimpang kunyit. Jurnal Ilmiah Kefarmasian 3, 21-30

Dewi R, Anwar E, Yunita KS (2014). Uji stabilitas fisik formula krim yang mengandung ekstrak kacang kedelai (Glycine max). Pharm Sci Res 1, 194-208

Gaikwad, Kale (2011). Formulation and in vitro evaluation for sun protection factor of Moringa oleifera Lamarck (Family Moringaceae) oil sunscreen cream. International Journal of Pharmacy and Pharmaceutical Sciences, 3

Moyo B, Masika PJ, Hugo A, Muchenje, V (2011). Nutritional characterization of Moringa(Moringa oleifera Lam.) leaves. African Journal of Biotechnology 10, 12925-12933

Naibaho DH, Yamkan VY, Weni Wiyono (2013). Pengaruh basis salep terhadap formulasi sediaan salep ekstrak daun kemangi (Ocinum sanchum L.) pada kulit punggung kelinci yang dibuat infeksi Staphylococcus aureus. Jurnal ilmiah Farmasi - UNSRAT 2

Panwar AS, Upadhyay N, Bairagi M, Gujar S, Darwhekar GN, Jain DK (2011). Emulgel:a review. Asian Journal of Pharmacy and Life Science 1

Priani SE, Darusman F, Humanisya H (2014). Formulasi sediaan emulgel antioksidan mengandung ekstrak etanol kulit batang kayu manis (Cinnamomum burmanni Nees ex. BL.). Prosiding Seminar Nasional 
Penelitian dan PKM Sains, Teknologi, dan Kesehatan 4, 103-110

Sari DK, Sugihartini N, Yuwono T (2015). Evaluasi uji iritasi dan uji sifat fisik sediaan emulgel minyak atsiri bunga cengkeh (Syzigium aromatikum). Pharmaciana 5, 115-120
Smaoui S, Hilma HB, Chobba IB, Kadri A (2013) Development and stability studies of sunscreen cream formulations containing three photo-protective filters. Arabian Journal of Chemistry 10, 1216-1222 Winarsi H (2007) Antioksidan alami dan radikal bebas. Yogyakarta, Kanisius, p 11-19 